\title{
FEASIBILITY STUDY OF A PIVOTED-PLATE SENSOR FOR SILAGE CORN YIELD MONITORING
}

\author{
MAHARLOUIE M.M., LOGHAVI M.* AND KAMGAR S. \\ Shiraz University, Shiraz, Iran. \\ *Corresponding Author: Email- loghavi@shirazu.ac.ir
}

Received: January 25, 2012; Accepted: March 09, 2012

\begin{abstract}
Crop yield map is a useful means to quantify yield variations within the fields and to provide a scientific basis for implementing site -specific crop management strategies. This research explores the feasibility of developing a new silage yield monitoring system by employing a new mass flow sensor based on using the momentum of chopped material impacting a pivoted plate loaded by a retractable spring installed at the end of a chopper discharge spout. A precise rotary potentiometer was used to measure the degree of pivoted plate rotation. To save and process the output voltage of the potentiometer, a programmable circuit comprising of AVR microcontroller ATMEGA series and MAX 232 microchip was used and the output data was sent to a portable computer for further processing. To calibrate the output signal of the sensor versus instantaneous chopped material flow rate, the chopper was fed artificially with predetermined mass flow rates of 6,8 and $10 \mathrm{~kg} \mathrm{~s}^{-1}$ of silage corn at five replications for each feeding rate. The results of statistical analysis showed high correlation between degrees of the pivoted-plate rotation and instantaneous feed rates with adjusted $R^{2}$ of 0.98 . To evaluate the accuracy of mass flow rate estimation, a platform scale weighing system was used during the field tests. The statistical analysis did not show any significant difference between sensor mass flow rate estimation and platform scale weighing system output. By using the resulted calibration equation, yield map of a silage cornfield was generated.
\end{abstract}

Key words- precision farming, yield monitoring, chopper, silage corn, pivoted-plate sensor

Citation: Maharlouie M.M., Loghavi M. and Kamgar S. (2012) Feasibility study of a Pivoted-Plate Sensor for Silage Corn Yield Monitoring. International Journal of Agriculture Science, ISSN: 0975-3710 \& E-ISSN: 0975-9107, Volume 4, Issue 2, pp-190-195.

Copyright: Copyright@2012 Maharlouie M.M., et al. This is an open-access article distributed under the terms of the Creative Commons Attribution License, which permits unrestricted use, distribution, and reproduction in any medium, provided the original author and source are credited.

\section{Introduction}

One of the most important topics in precision farming is preparing yield maps for grain or non-grain crops. Crop producers use these maps to find the existence of problems hindering their access to the full potential yield and profit in their fields. The most complicated part of yield map technology is determining the mass flow rate (mass/time) of the harvested crop during harvesting operations. Yield sensors as reported by Loghavi and Almaee (2009) are based on a wide variety of measurement methods including paddle wheel volume flow sensor (Schueller et al., 1987; Searcy et al., 1989; Schnug et al., 1993), pivoted auger (Wagner and Schrock, 1989), capacitance sensor (Stafford et al., 1991), ultrasonic sensor (Klemme et al., 1992), strain gage-based impact sensor (Borgelt, 1993), elevator-based flow sensor (Howard et al., 1993), gamma ray sensor (Stafford et al., 1991; Massey Fergu- son, 1993), infrared sensor (Hummel et al.,1995), and x-ray techniques (Arslan et al., 2000)[16].

Cereal grain yield monitors are well developed and experimental methods used by researchers have been commercialized due to the availability of proven combine grain yield monitors. However, up to now limited commercial methods have been developed for non-grain crops mainly because of diverse methods of harvesting and substantial differences between these crops regarding their physical and mechanical properties. Several research projects have been conducted and many investigations are still in progress to develop practical techniques in this area.

Godwin et al (1999) developed a yield mapping system for use in non-grain crops (i.e. roots and forage) using the measurement of mass accumulation rate. The concept was realized by instrumenting a high-sided trailer to record the rate of accumulation of crop 
mass as the trailer followed the harvester. The location of the trailer was recorded using a differential GPS with a linked data set to log the position and the processed mass information. The mean yield values of sugar beet and potato crops taken from the yield map and from samples measured by batch harvesting were not significantly different [10]. Pelletier and Upadhyaya (1999) developed a continuous mass flow-type yield-sensing device equipped with load cells along with a differential global positioning system (DGPS) for mounting on a processing tomato harvester to collect spatially variable yield data in real-time. Their results showed high correlation of 0.997 between load cells output and clean tomato mass flow rate [22]. Cotton yield monitor systems have been developed and tested [7, 23, 24, 28, 29, 30, 32, 34, 40, 41, 46, 47], and several versions of a cotton yield monitor have come to market. All commercial cotton yield monitors use the principle of optical attenuation using a light-emitter array and a light-detector array mounted opposite to each other on a cotton picker's pneumatic duct. The light attenuation signal is converted by the data acquisition system to an estimate of the cotton mass flow rate [33]. For peanut yield monitoring, development of a load cell-based yield monitor [7, 39] and an optical-based yield monitor [35] have been reported.

For yield monitoring and mapping of root crop (i.e. potato, sugar beet, etc.) yields, the following measurement systems have been reported: radiometric [2], load cells in belt conveyors [4, 42, 43], image analysis [14, 25], pivoted table with a load cell [27], bounce plate $[8,9]$ and weighing frame with load cells and speed sensors [37], curved impact plate [11].

For sugar cane yield monitoring the following attempts have been reported: development of hydraulic pressure and flow measurement system [5], construction of load cell-based mass measurement trailer [26], weight scale yield sensor [3], load cell transducers and speed detectors mounted on side conveyor [21] and load cells as a billet weighing instrument set up on the harvester side conveyor just before the sugar cane billets are dropped into an infield trailer [17].

In silage and forage crops, investigations were initiated by instrumenting a silage corn harvester with strain gauge-based torque sensors fitted on main blower shaft and main drive shaft of cutter head, feed rolls and front attachment [38]. Auernhammer et al. (1995) used a radioactive transmitter and receiver to find a relationship between feed rate changes of dry silage crop and changes in the intensity of radioactive wave received by the detector. Although they found good correlation between these parameters, this technique was banned due to US food industry regulations that prevented food producers from using radioactive waves during food processing [1].

Missoten et al. (1997) installed an impact plate sensor in spout of a drawn chopper. A deflector was used to guide chopped material toward the impact sensor. To compensate the effect of speed changes of passing material, a radar-type speed sensor was also installed. Results showed a linear relation $\left(R^{2}=0.985\right)$ between mass flow rate and output data through the sensor [20].

Wild and Auernhammer (1999) equipped a round baler with straingauge load cells installed on the axle and drawbar to prepare a yield map. They conducted tests in stationary and on-the-go modes. The results showed that in stationary mode, the difference between actual mass flow rate and sensor output was only $1 \%$ but in on-the-go mode, the difference was $10 \%$ due to vibrations of the moving vehicle [44].

Martel and Savoie (2000) equipped a pull-type forage harvester with four different types of sensors to estimate mass flow rate and moisture content. Sensors measured feed roll displacement, crop impact force against a hinged plate, the frequency drop of a capacitance controlled oscillator and number of light beam interruptions by forage particles in the spout. When testing in a cornfield, good correlations were obtained between estimated mass-flowrate and either the feed roll displacement $\left(R^{2}=94 \%\right)$ or the crop impact force $\left(R^{2}=0.95\right)$ [18]. Savoie et al. $(2002)$ in a similar investigation to Martel and Savoie (2000) equipped a forage harvester and a high-dump wagon with five types of sensors to measure mass-flow rate. Final results showed that impact force in the spout produced a very good linear correlation with mass-flow rate $\left(R^{2}=0.951\right)$. Feed roll displacement produced the second best linear correlation with mass-flow rate $\left(R^{2}=0.863\right)$. Torque at the PTO shaft and at the cutter-head required a moisture correction to improve correlation with mass-flow rate. The capacitancecontrolled oscillator was poorly correlated with mass-flow rate but yielded the best correlation with moisture content $\left(R^{2}=0.662\right)$ [30]. Lee et al. (2002) constructed a trailer equipped with load cells that could continuously measure the weight of chopped material. They used a blue-tooth data transmitter to transmit moisture data from a capacitance type moisture sensor mounted in an opening made in the middle of a spout of the silage chopper to a host computer. The masses of the empty and full silage wagon were measured with a platform scale before and after harvesting, and were compared with load cell measurements in the silage yield mapping system. By using GPS data and sensors data, they could prepare a yield map for silage crop [15].

Kumhala and Prosek (2003) developed and evaluated a torque meter and an impact force sensor simultaneously on a three-point linkage type mower-conditioner. They concluded that the impact force sensor was prefered to the torque sensor due to the lower cost and less sensitivity to the kind of crop being harvested [12].

Kumhala et al., 2007 developed a parallel plate capacitance sensor (capacitor) operating at $27 \mathrm{MHz}$ frequency was designed for forage mass determination. Laboratory tests showed that moisture content as well as contact pressure of material placed between the plates influenced the sensor's output signal. The results showed a strong relationship between the weight of material and the sensor's signal. They claimed that it is possible to recommend this experimental method for further research and development [13]. Kumhala et al. (2010) tested a parallel plate capacitive throughput sensor for the purpose of chopped maize throughput measurement. They recognized a non-linear dependence between the sensor output signals and material throughput. They recommended that the material moisture content have to be respected during capacitive throughput sensor calibration.

As mentioned above, many studies have been focused on measuring the impact force of chopped materials impacting a deflector plate in the spout of chopper harvester, but scientist claimed that load cells were highly sensitive to machine vibrations in the field causing errors in measurements. The objective of this research was to investigate the feasibility of using a pivoted plate sensor in the spout of the silage corn chopper for real-time measurement of chopped material throughput in preparation of a site-specific yield 
map. The main advantage of this new method is installing the mass flow sensor without any major modification in conventional system of the harvester. The other advantage of the suggested method is using a precise potentiometer to measure angular rotation of a pivoted plate that is indirectly related to the momentum of chopped materials impacting the plate instead of measuring the impact force directly by a load cell as mentioned in reviewed literatures.

\section{Materials and Methods \\ Theoretical criteria}

A throughput flow rate sensor was developed and installed to meter the rate of chopped material leaving the spout of the chopper. The designed mechanism consisted of a pivoted curved plate with a re-coil spring mechanism and a precise rotary potentiometer to measure angular rotation of the curved plate due to the momentum of chopped materials leaving the spout.

\section{Design and construction of mechanical parts}

The curved plate was shaped and its main pivot and recoil spring and lever mechanism were machined and fabricated according to the designed drawing (Fig. 1.).
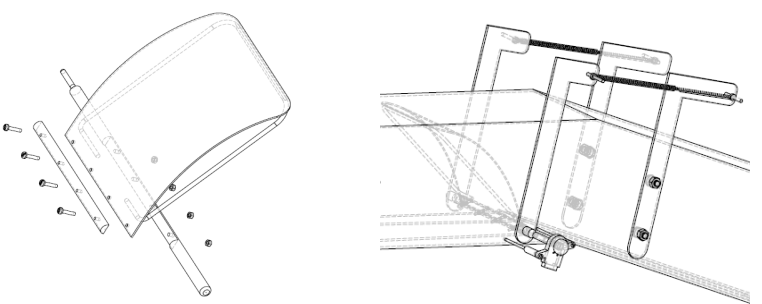

Fig. 1- Drawing map of pivoted plate and accessories (lever mechanism, spring and potentiometer)

To design the proper recoil spring, calculations were performed with the following facts and assumptions:

By assuming ground speed of $3.2 \mathrm{~km} \mathrm{~h}^{-1}\left(0.9 \mathrm{~m} \mathrm{~s}^{-1}\right)$, the maximum feed rate of chopper in this research was estimated to be about 10 $\mathrm{kg} \mathrm{s}^{-1}$ (depends on crop yield, moisture content, swath width and harvester travel speed). By knowing some geometrical and technical specifications of the chopper harvester (CLAAS, JAGUAR62) such as cutter head diameter and rotational speed, coefficient of friction between chopped material and spout inside surface $(\mu=$ 0.49), the height and total distance between cutter head and impact plate, the velocity of material before impacting the curved plate sensor ( $\mathrm{V}_{\mathrm{bl}}$ as shown in Fig. 2) was calculated (Eq. 2). To calculate the material velocity after impacting the pivoted plate sensor, the minimum required velocity of materials to reach the platform scale weighing system was considered.

To facilitate the calculations, the following assumptions was considered: a) Chopped materials having a projectile motion and b) Neglecting the effect of drag force (Eq. 4). By knowing the required parameters such as before and after impact velocities and the desired linear displacement of the designed spring at the maximum assumed material feed rate $(X=0.17 \mathrm{~m})$, the proper spring was selected with the specifications given in table1. The curved impact plate and its recoil spring and linkages after installation on the chopper spout are shown in figure 3 .

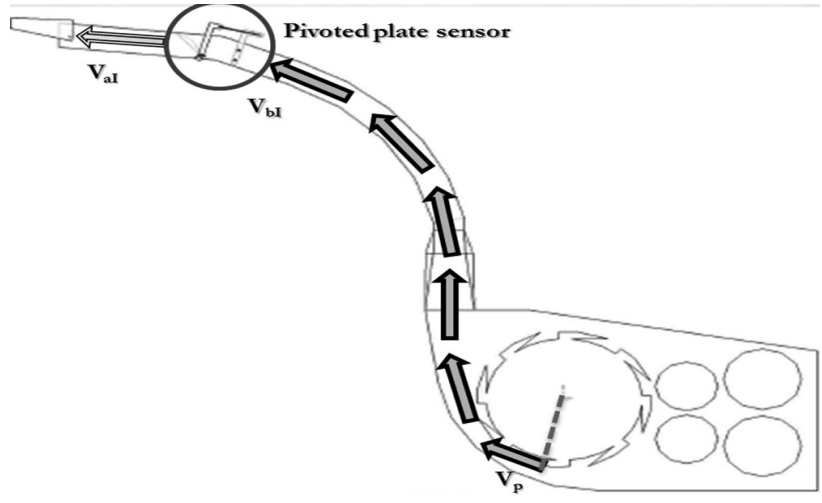

Fig. 2- Schematic Diagram of velocity changes in chopper chute (1)
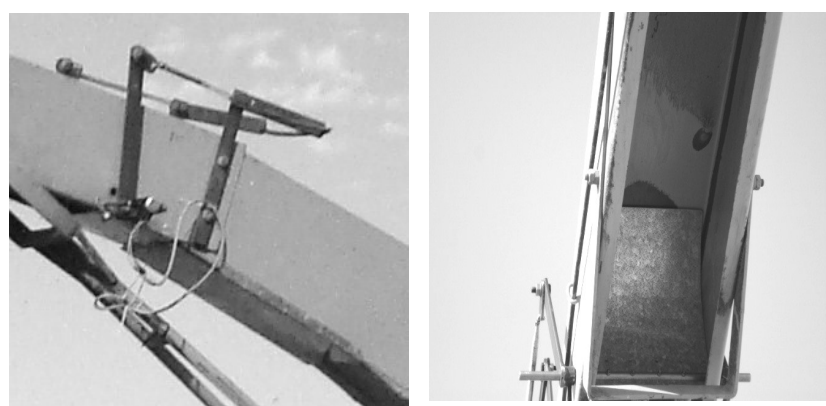

$$
\begin{aligned}
& F_{I}=m a \Rightarrow F_{I}=m \frac{d v}{d t} \Rightarrow \int_{d} F_{d} d t=m\left(v_{a I}-v_{b S}\right) \\
& F_{z} \approx\left[\frac{m\left(v_{a t}-v_{s t}\right)}{\Delta}\right] \\
& \frac{1}{2} m v_{\sigma}^{2}=\frac{1}{2} m v_{b J}^{2}+m g h+\mu \cdot m g d \\
& v_{z}=\frac{2 \pi n_{s} r_{s}}{60}=\frac{2 \pi \times 950 \times 0.35}{60}=34.82(\mathrm{~m} / \mathrm{s}) \\
& \text { (2) } \Rightarrow v_{b I}-\left(v_{p}^{2}-2 g h-2, \mu \cdot g d\right)^{p .5}-33.75(\mathrm{~m} / \mathrm{s}) \\
& Y=\frac{1}{2} g\left(\frac{R}{v_{e r} \cos \theta}\right)^{2}+R \times \tan \theta
\end{aligned}
$$

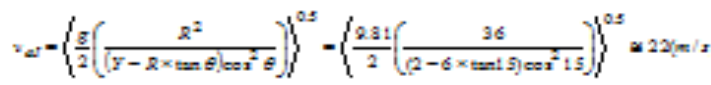

$$
\begin{aligned}
& F_{f}=10 \times(22-33.75) / 1=117.5 \mathrm{~N} \\
& F_{f}=k \times x \Rightarrow k=117.5 / 0.17 \cong 690 \mathrm{~N} / \mathrm{m}
\end{aligned}
$$

\section{Design and construction of electronic circuit}

To measure the degree of curved-plate rotation due to impact of chopped material, a precise rotary potentiometer (AB,800FPPOT5, $50 \mathrm{k} \Omega$, Mexico) was used. For real-time data recording on a portable computer, an AVR micro controller model ATMEL 16L was used. The output signal of the rotary sensor was connected to ADC port of the micro controller and sent to portable computer via max232 microchip and serial to USB convertor cable, every 0.1 second. A Schematic diagram of the electronic circuit designed for this study is shown in figure 4 . 


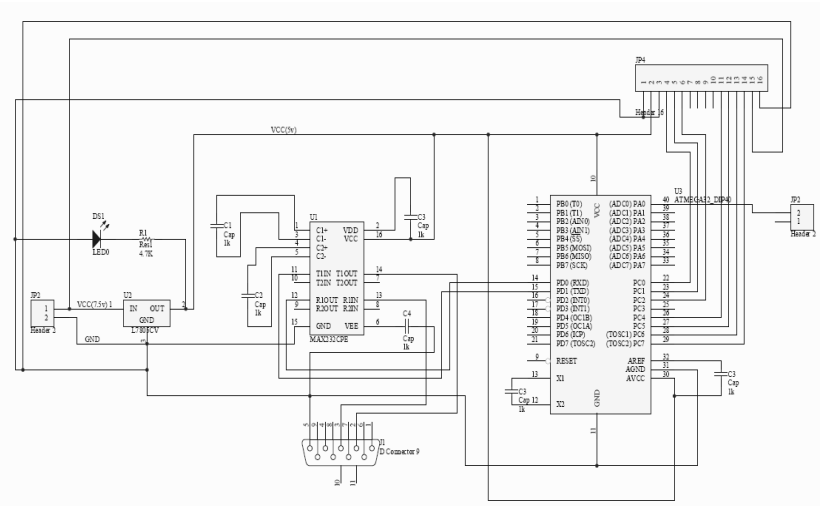

Fig. 4- Schematic diagram of the electronic circuit

\section{Platform scale weighing system}

To evaluate accuracy of the mass flow sensor in field conditions, a drawn type wagon was equipped with a sub frame and a precise weighing load cell to continuously weigh the chopped material poured into its storage bag (Fig. 5). This wagon was used as a control treatment (accurate reference) in field trials.

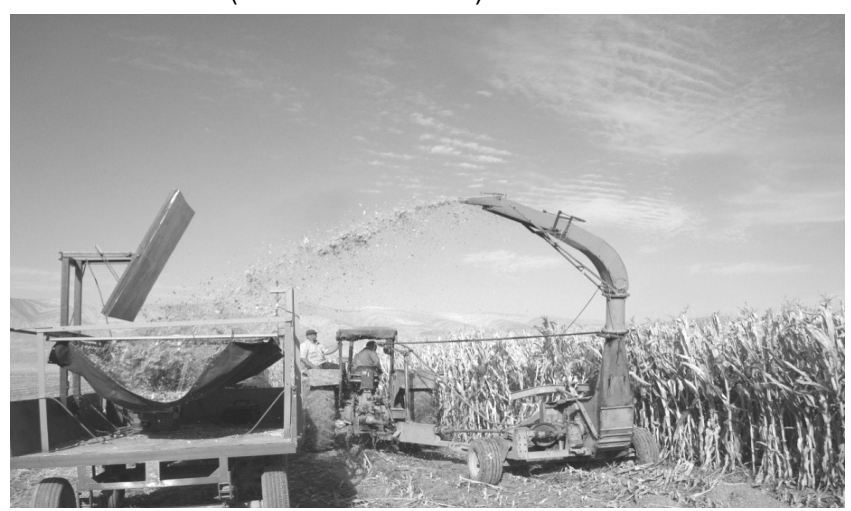

Fig. 5- A field test of the sensor using platform scale weighing system

\section{System calibration and testing}

In order to calibrate and test the performance of the yield monitoring system, field tests were conducted in the experimental fields of the College of Agriculture, Shiraz University, Shiraz, Iran.

To calibrate the sensor, a part of the test field was prepared with artificially selecting crop densities giving predetermined feed rates of 6,8 and $10 \mathrm{~kg} \mathrm{~s}^{-1}$ each in 5 replications. These feed rates were controlled by varying the speed of the tractor based on anticipated yield determined by previous sampling in the field. The instant feed rate at time $n$ determined by subtracting accumulated mass of chopped material at time n-1 from the accumulated mass at time $\mathrm{n}$. Finally, a yield map was created for a small plot with three crop rows, each 20 meters long using geographical software Surfer 8.0 .

\section{Results and Discussion \\ System calibration}

In order to find a calibration curve between the crop feed rate and degree of the curved plate rotation, data must be normally distributed and for a more precise calibration curve, a proper statistical tool should be employed to eliminate the outliers in each treat- ments. To fulfill these requirements, statistical analyses were conducted using statistical software SPSS 13.0. The normal distribution of the data in each treatment was verified by conducting Kolmogorov-Simirnov normality test. A confidence interval ((1-a) $\times 100=95 \%$ ) around the mean was used as a criterion to eliminate outliers in each feed rate treatment. (Eq. 7):

Confidence interval around the mean $=$ Mean of population \pm Standard Error of Meanxta/2

In order to use the rotation of the pivoted-plate as an indicator of the instantaneous mass flow rate in the field, a calibration curve was drawn on the experimental data after eliminating outliers as shown in figure 6.

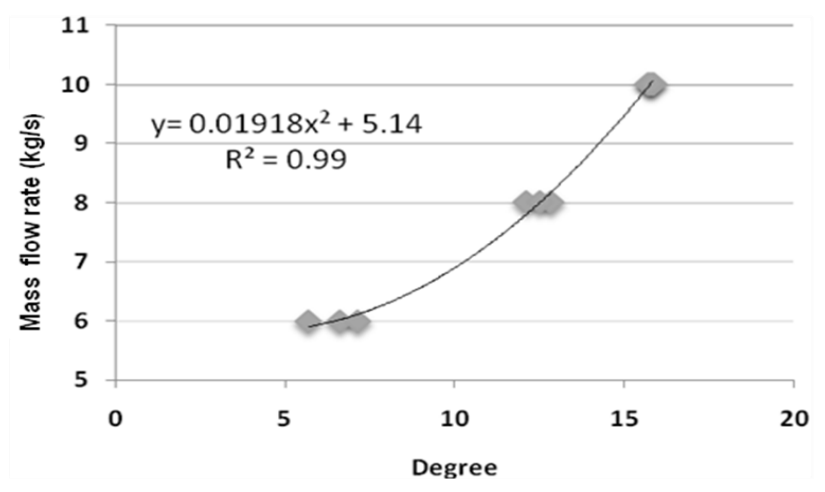

Fig. 6- Relation of pivoted plate angular rotation and instantaneous mass flow

\section{Evaluation of the sensor output accuracy}

To compare the sensor output and instant feed rates of platform scale weighing system statistically, a t-test was used. The results revealed no significant differences between sensor output and platform scale feed rates at $5 \%$ confidence level. These two data sets were correlated by correlation coefficient of 0.78 and as an another statistical tool to measure how well the estimated yield by pivoted plate sensor fits actual instantaneous yield measured by the platform scale, root mean squared error (RMSE) was calculated and it was equal to 1.505 .

\section{Result of yield map creation}

The resulting yield map (Fig. 7) shows the mean yield of $5 \mathrm{~kg} \mathrm{~m}^{-2}$ with standard deviation of $2.0 \mathrm{Kg} \mathrm{m}^{-2}$. The minimum yield was 2.5 $\mathrm{kg} \mathrm{m}^{-2}$ and the maximum yield was $10.8 \mathrm{~kg} \mathrm{~m}^{-2}$.

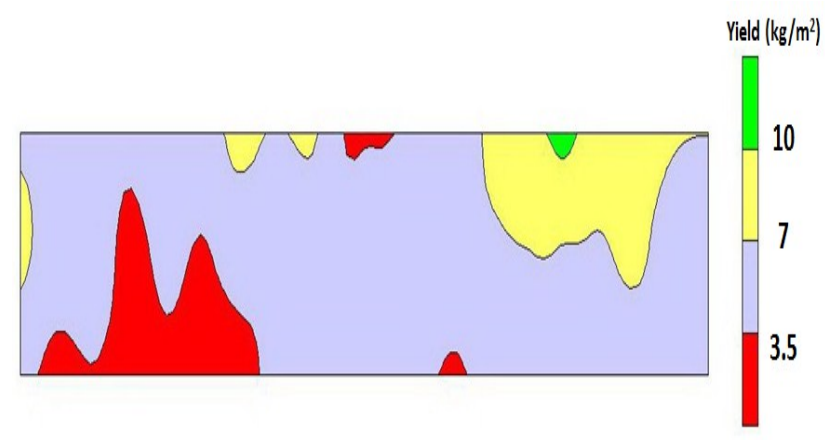

Fig. 7- A typical silage corn yield map of the test field 


\section{Conclusion}

In this research, the feasibility of using a pivoted plate mass flow sensor for silage corn yield monitoring was investigated. Results of statistical analysis for calibration and field tests showed a highly correlated relation between angular rotation of pivoted plate and instantaneous mass flow rate. More investigations are needed to evaluate this suggested approach at different moisture levels and maturity stages of plant to find a more general calibration equation for mass flow prediction.

\section{Nomenclature}

\begin{tabular}{|c|c|}
\hline $\mathrm{F}_{\mathrm{I}}$ & Impact force of material due to pivoted plate sensor, $\mathrm{N}$ \\
\hline $\mathrm{V}_{\mathrm{aI}}$ & Speed of material after impacting pivoted plate sensor, $\mathrm{m} \mathrm{s}^{-1}$ \\
\hline $\mathrm{V}_{\mathrm{bI}}$ & Speed of material before impacting pivoted plate sensor, $\mathrm{m} \mathrm{s}^{-1}$ \\
\hline $\mathrm{V}_{\mathrm{p}}$ & $\begin{array}{l}\text { Peripheral speed of cutting cylinder = Speed of chopped materi- } \\
\text { al leaving cutting head, } \mathrm{m} \mathrm{s}^{-1}\end{array}$ \\
\hline $\mathrm{n}_{\mathrm{c}}$ & Rotary speed of cutter head, rpm \\
\hline $\mathrm{r}_{\mathrm{c}}$ & Radius of cutter head, $\mathrm{m}$ \\
\hline$m$ & $\begin{array}{l}\text { Maximum mass of material impacting the pivoted plate in im- } \\
\text { pact duration ( } 1 \text { second period), } \mathrm{kg}\end{array}$ \\
\hline$\Delta$ & Impact duration (1 second) \\
\hline$g$ & Gravitational acceleration, $\mathrm{m} \mathrm{s}^{-2}$ \\
\hline $\mathrm{h}$ & Height of discharge spout, $\mathrm{m}$ \\
\hline$d$ & Total distance between cutter head and pivoted plate sensor, $\mathrm{m}$ \\
\hline$\mu$ & $\begin{array}{l}\text { Friction coefficient between chopped material and spout inside } \\
\text { surface }\end{array}$ \\
\hline k & Recoil spring stiffness coefficient, $\mathrm{N} \mathrm{m}^{-1}$ \\
\hline $\mathrm{x}$ & Desired linear displacement of recoil spring, $m$ \\
\hline Y & $\begin{array}{l}\text { Vertical Displacement between chopper spout and platform } \\
\text { scale weighing system, } m\end{array}$ \\
\hline $\mathrm{R}$ & $\begin{array}{l}\text { Horizontal Displacement between chopper spout and platform } \\
\text { scale weighing system, } m\end{array}$ \\
\hline$\theta$ & Discharge angle of chopped material trajectory \\
\hline
\end{tabular}

\section{Acknowledgment}

Authors should express their acknowledgment toward Dr. S. M. Nassiri and Professor Jonathan Chaplin for their guidance and helps and also Shiraz University for its technical supports.

\section{References}

[1] Auernhammer H., Demmel M. and Pirro P.J.M. (1995) Yield measurement on self propelled forage harvesters. ASAE Paper No. 95-1757.

[2] Baganz K. (1991) International Symposium on Locating Systems for Agricultural Machines, Godollo, 18.

[3] Benjamin C.E., Mailander M.P. and Price R.R. (2001) Sugar cane yield monitoring system. ASAE 011189.

[4] Campbell R.H., Rawlins S.I. and Shufeng H. (1994) Monitoring methods for potato yield mapping. ASAE 94-1584.

[5] Cox G., Harris H. and Pax R. (1997) Australian Society of Sugar Cane Technologists, 38-43.

[6] Durrence J.S., Perry C.D., Vellidis G., Thomas D.L. and Kvien C.K. (1998) Evaluation of commercially available cotton yield monitors in Georgia field conditions. ASAE 983106.

[7] Durrence J.S., Hamrita U.T.K. and Vellidis G. (1999) Precision
Agriculture 1, 301-317.

[8] Ehlert D. (1996) Landtechnik 51(H.1), 20-21.

[9] Ehlert D. (1999) the 2nd European Conference on Precision Agriculture, 797-804.

[10]Godwin R.J., Wheeler P.N., O'Dogherty M.J., Watt C.D. and Richards T. (1999) Computers and Electronics in Agriculture 23, 85-101.

[11]Hennens D., Baert J., Broos B., Ramon H. and De Baerdemaeker J. (2003) Biosystems Engineering 85 (4), 425-436.

[12]Kumhala P. and Prosek V. (2003) Precision Agriculture 4, 413 $-419$.

[13]Kumhála F., Kvíz Z., Kmoch J. and Prošek V. (2007) RES. AGR. ENG., 53 (4), 149-154.

[14]Larsson K. (1994) Teknik for Lantbruket, 43, 7.

[15]Lee W.S., Schueller J.K. and Burks T.F. (2002) ASAE Annual International Meeting. 021165.

[16]Loghavi M. and Almaee M. (2009) Agricultural Engineering International: the CIGR Ejournal.

[17]Magalhaes P.S.G. and Cerri D.G.P. (2006) Biosystems Engineering 96 (1), 1-6.

[18]Martel H. and Savoie P. (2000) Can. Agric. Eng. 42,123-129.

[19]Meriyam J.L. and Kraige L.G. (2002) Engineering Mechanics, II: Dynamics. Fifth edition. John Wiley \& Sons.

[20]Missoten B., Brooks B., Strubbe G. and De Baerdemaeker J. (1997) The first European conference on Precision Agriculture, Warwick University, 7-10, 529-536.

[21]Pagnano N.B. and Magalhaes P.S.G. (2001) The Third European Conference on Precision Agriculture, 839-843.

[22]Pelletier G. and Upadhyaya S.K. (1999) Computers and Electronics in Agriculture 23, 103-117.

[23]Perry C.D., Vellidis G., Wells N. and Kvien C. (2001) The Beltwide Cotton Conference, ed: D.A. Richter, Memphis, Tenn. National Cotton Council of America. 328-339.

[24]Perry C.D. and Vellidis G. (2005) Cotton yield monitor instantaneous accuracy during steady-state and step-input conditions. ASAE 051129.

[25]Persson A. (1998) The 1st International Conference on Geospatial Information in Agriculture and Forestry, Ann Arbor, MI, 618-623.

[26]Pierossi M.A. and Hassuani S.J. (1997) Semina'rio Copersucar de Tecnologia Agrono^mica 7, Piracicaba, Brazil, 263-265.

[27]Rawlins S.L., Campbell G.S., Campbell R.H. and Hess J.R. (1995) The 2nd Intl. Conf. Site-Specific Management for Agricultural Systems.

[28]Roades J.P., Beck A.D. and Searcy S.W. (2000) The Beltwide Cotton Conference, 404-408.

[29]Sassenrath-Cole G.F., Thomson S.J., Williford J.R., Hood K.B., Thomasson J.A., Williams J. and Woodard D. (1999) The Beltwide Cotton Conference, 364-366.

[30]Savoie P., Lemire P. and Thériault R. (2002) Applied Engineering in Agriculture 18(4), 389-397.

[31]Sirvastava A.K., Georing G.E. and Rohrbach R.P. (1993) Engineering Principle of Agricultural Machines. ASAE, 601p.

[32] Sui R., Thomasson J.A., Mehrle R., Dale M., Perry C. and Rains G. (2004) Computers and Electronics in Agriculture 42, $149-160$.

[33]Thomasson J.A., Pennington D.A., Pringle H.C., Columbus 
E.P., Thomson S.J. and Byler R.K. (1999) Applied Engineering in Agriculture 15(1), 11-17.

[34]Thomasson J.A. and Sui R. (2000) The Beltwide Cotton Conference, 408-410.

[35]Thomasson J.A., Sui R., Wright G.C. and Robson A.J. (2006) Applied Engineering in Agriculture 22(6), 809-818.

[36]Upadhyaya S.K. (1999) The Fourth International Conference on Precision Agriculture.

[37]Van Canneyt T. and Verschoore R. (2000) Agricultural Engineering into the Third Millennium, 331-332.

[38]Vansichen R. and De Baerdemaeker J. (1993) Journal of Agricultural Engineering Research, 55, 1-10.

[39]Vellidis G., Perry C.D., Durrence J.S., Thomas D.L., Hill R.W., Kvien C.K., Hamrita T.K. and Rains G. (2001) Transactions of the ASAE 44(4), 775-785.

[40]Vellidis G., Perry C.D., Rains G., Thomas D.L., Wells N. and Kvien C.K. (2003) Applied Engineering in Agriculture 19(3), 259-272.

[41]Wallace T.P. (1999) Computers and Electronics in Agriculture 23, 1-8.

[42]Walter J.D., Backer L.F. and Hofman V.L. (1996) Sugar beet yield monitoring for site-specific farming, ASAE 961022.

[43]Walter J.D. and Backer L.F. (2003) Precision Agriculture 4, 421-31.

[44]Wild K. and Auernhammer H. (1999) Computers and Electronics in Agriculture 23, 119-132.

[45]Wilkerson J.B., Kirby S., Hart W.E. and Womac A.R. (1994) Real-time cotton flow sensor. ASAE 94-1054.

[46]Wilkerson J.B., Moody F.H. and Hart. W.E. (2002) Applied Engineering in Agriculture 18(2), 153-159.

[47]Wolak F.J., Khalilian A., Dodd R.B., Han Y.J., Keshlkin M., Lippert R.M. and Hair W. (1999) The Belt wide Cotton Conference, 361-364. 